Man and Nature

L'homme et la nature

\title{
Matter, Mind and Active Principles in Mid Eighteenth-Century British Physiology
}

\section{John P. Wright}

Volume 4, 1985

URI : https://id.erudit.org/iderudit/1011834ar

DOI : https://doi.org/10.7202/1011834ar

Aller au sommaire du numéro

Éditeur(s)

Canadian Society for Eighteenth-Century Studies / Société canadienne d'étude du dix-huitième siècle

ISSN

0824-3298 (imprimé)

1927-8810 (numérique)

Découvrir la revue

Citer cet article

Wright, J. P. (1985). Matter, Mind and Active Principles in Mid

Eighteenth-Century British Physiology. Man and Nature / L'homme et la nature, 4, 17-27. https://doi.org/10.7202/1011834ar

Copyright (C Canadian Society for Eighteenth-Century Studies / Sociéte canadienne d'étude du dix-huitième siècle, 1985
Ce document est protégé par la loi sur le droit d'auteur. L'utilisation des services d'Érudit (y compris la reproduction) est assujettie à sa politique d'utilisation que vous pouvez consulter en ligne.

https://apropos.erudit.org/fr/usagers/politique-dutilisation/ 


\section{Matter, Mind and Active Principles in Mid Eighteenth-Century British Physiology}

In his book Les Sciences de la Vie dans la Pensée Française du XVIIIe Siècle, Jacques Roger has written:

Les dogmes les plus généralement admis par la science de 1680 , la nécessité de l'expérience, la conception d'une matière purement passive et composée de corpuscules soumis aux seules 'ois du movement', toutes ces idées fondamentales ont été imposées, dans la première moitié du siècle, par des philosophes. Après 1670 , elles sont prises en charge par les savants, et l'on pourra être 'mécaniciste' et 'corpusculariste' toute en étant cartésien avec Rohault, gassendiste avec Guillaume Lamy, chimiste avec Duncan ou animiste avec Claude Perrault. ${ }^{1}$

The general philosophical situation described by Roger is, it seems to me, as true for Britain as it is for France. In particular, the basic doctrine of the passivity of matter lasts well into the eighteenth century. In his Essay on Regimen published in 1740 the 'animist' George Cheyne wrote that Matter or Body ... is naturally passive, and to make it active, or capable of Self-motion, is an absolute Contradiction and Impossibility.'2 Similarly the 'mechanist' David Hartley, writing eight years later, says that Matter is a mere passive Thing, of whose very Essence it is, to be endued with a Vis Inertiae ... ${ }^{3}$ Similar claims can be found in many writers on medical topics in Britain in the first half of the eighteenth century. And yet, 
because of their very generality, such claims tell us little about the views of life and nature espoused by such writers.

Many British writers on the sciences of life in the first half of the eighteenth century espoused some form of Newtonian natural philosophy. Newton's public philosophical spokesman Samuel Clarke had written in his famous correspondence with Leibniz that 'matter (is) lifeless, void of motivity, unactive, and inert. ${ }^{\prime}$ Yet this is only the beginning of the story - even in the description of the universe apart from plants and animals. The passivity of matter, according to Clarke, results in the fact that the amount of force does naturally diminish continually in the material universe' (p. 112). Similarly in his Opticks Newton himself wrote that the mechanical motion in the universe is 'always upon the Decay' due to the 'Tenacity of Fluids, and Attrition of their Parts, and the Weakness of Elasticity in Solids.' He goes on to draw the following conclusion:

Seeing therefore the variety of Motion which we find in the World is always decreasing, there is a necessity of conserving and recruiting it by active Principles, such as are the cause of Gravity, by which Planets and Comets keep their Motions in the Orbs, and Bodies acquire great Motion in falling; and the cause of Fermentation, by which the Heart and Blood of Animals are kept in perpetual Motion and Heat .... .5

According to Newton and Clarke there are active powers in the universe which are required to recruit the loss of motion due to the passivity of matter. These active powers are like those which cause 'perpetual Motion and Heat' in animals. Clarke states that any sort of increase in motion must always arise from 'a principle of life and activity' (The LeibnizClarke Correspondence, p. 110).

The nature of these non-material active powers was left obscure by Newton and this obscurity led to a fascinating dialectic in eighteenthcentury British natural philosophy. To what extent can such forces be considered immanent in nature itself? To what extent do the active powers of animals and plants differ from those to be found in the universe in general? Are such active powers associated with a particular physical substance - the interparticulate aether - as Newton suggested in Query 18 which appeared in the 1717 Opticks?

One physiologist who, it seems to me, is clearly writing in the context of such questions is the Edinburgh physician, Robert Whytt. Whytt was an excellent experimentalist and is commonly recognized as having made an important contribution to our understanding of reflex action. ${ }^{6} \mathrm{He}$ engaged in an important dispute with Albrecht von $\mathrm{Haller}^{7}$ and his ideas 
on muscular motion were adopted by Fouquet and Ménuret in the articles of the Encyclopédie entitled 'Mort' and 'Sensibilité'. ${ }^{8}$

When considered apart from the context in which he himself was writing, it is easy to think of Whytt as an 'animist'; but the fact that he is careful to distinguish his views from those of contemporary followers of Georg Stahl suggests that such a label is misleading. In Section xi of his Essay on the Vital and other Involuntary Motions of Animals, Whytt argues that the continuous motion of animals is 'not owing to any mechanical or even material causes alone, but to the energy of a living principle capable of generating motion.' His argument is based on the claim that animals are perpetual motion systems. Whytt insists that perpetual motion cannot result from material nature alone, and in so doing he appeals directly to principles of the Newtonian philosophy. He notes that Stephen Hales has established that in every circulation, the blood loses $9 / 10$ of the momentum communicated to it by the left ventricle of the heart.' Such a loss is due to 'friction'. However, 'matter, in its own nature inert' is not capable of regenerating this lost motion. Whytt writes that, 'a perpetual motion is, in the opinion of the ablest philosophers, above the powers of mechanism, and inconsistent with the known laws of matter and motion.' In support of this claim Whytt appeals to a note by Samuel Clarke in John Clarke's edition of Rohault's System of Natural Philosophy. ${ }^{9}$ In the note Clarke claims that a perpetuum mobile on purely mechanical principles implies an absurdity. ${ }^{10}$ We have already seen that this doctrine was explicit in other major writings of Clarke and Newton himself.

It seems clear, then, that in claiming that self-movement is inconsistent with the known laws of movement Whytt was adopting a standard Newtonian doctrine. The claim in the conclusion to his Essay that 'the motions of our small and inconsiderable bodies, are all to be referred to the active power of an immaterial principle ${ }^{\prime 11}$ appears to be equally orthodox. Indeed it was to such a principle that Newton himself appealed in order to explain the continuous motion in the universe as a whole.

But when we come to examine what Whytt goes on to say about the 'active power,' we can see that his philosophical physiology is anything but uncontroversial. Whytt writes that

the human body ought not to be regarded (as it has too long been by many Physiologists) as a mechanical machine, so exquisitely formed, as, by the mere force of its construction, to be able to perform, and continue, the several vital functions; things far above the powers of a mechanism! But as a system ... whose motions are all owing to the active power, and energy, of an immaterial 
sentient principle, to which it is united, and by which every fibre of it is enlivened and actuated. ${ }^{12}$

Whytt interprets the 'active power' which is the source of all animal motion as a 'sentient principle' which is located in every fibre of the body. Whytt's sentient principle does not merely recoup the loss of motion in the body, but it accounts for every single motion which has the living body itself as its immediate source. Whytt's complete rejection of the conception of the human body as a machine is closely related to his claim that all involuntary motions, including the beating of the heart, require a stimulus. Whytt argued that the motions of animal fibres, from a stimulus, most certainly bespeak a feeling, and cannot be explained unless we admit it' (p. 389). The idea that the reaction of the body fibres (even when the organs are removed from the body!) is due to a sentient or feeling principle in them, is central to Whytt's physiology. In section $x$ of his Essay, Whytt carefully considers and shows the implausibility of a variety of mechanical and material theories which were put forward in his day to explain the reactions of muscle fibres to stimuli.

It is important to recognize that in ascribing the response of an organism to a sentient principle, Whytt thought that he was providing a positive explanation of the phenomena. Whytt notes that none of the current mechanical theories can explain why a sharp needle should produce a far greater response than 'a blunt one acting upon it with equal force' (p. 231). Neither the mechanical nor the materialistic theories can explain why

A stimulus applied to the muscles of animals when laid bare produces, instead of only one contraction lasting for a considerable time, several contractions and relaxations alternately succeeding each other, which ... are repeated after longer intervals, as the force of the irritating cause is diminished.

However, Whytt thinks that these particular responses of the fibres may be explained if we postulate

A sentient Principle, which, in order to the getting rid of the pain or uneasy sensation that arises from the irritation of the muscle, determines the influence of the nerves into its fibres more strongly than usual. (pp. 242-43)

According to Whytt we can make sense of the specific reaction of the living fibres when we see that it is 'more or less forcible, and repeated after shorter or longer intervals, in proportion as the stimulus and painful sensation hence ensuing are stronger or weaker' (ibid.). In fact Whytt's sensi- 
ble principle seems to be a kind of inherent pain principle. He believed that such a principle operates even when the head of a frog is separated from the rest of its body. He is usually credited with having discovered that there is an inhibitory period after the decapitation of a frog in which the reflex reaction is delayed. But Whytt's explanation seems even more remarkable than the phenomenon itself. Whytt asks: 'Is not the irritation of the toes, immediately after decollation, rendered ineffectual to produce any motion in the muscles of the legs and thighs, by the greater pain occasioned by the cutting off of the head?' It seems that the frog's mind is too concerned with the pain involved in the loss of its head to react immediately to the relatively minor pain of its toes being pinched! It is only after the former pain has subsided that, after a half an hour, the nerve will again be able to react to the stimulus. In support of his explanation, Whytt appeals to the 'observation made by Hippocrates, viz. That a greater pain destroys, in a considerable degree, the feeling of a lesser one ....' 13

It is clear, then, that Whytt's sentient principle is not merely a Newtonian 'active power' which accounts for the continuous motions of animals, but also an explanatory principle put forward to account for the specific responses of living tissue to a stimulus. While Whytt admits that there is a great deal about the soul which we do not understand, he is concerned to argue that the appeal to the sentient principle is more than a refuge of ignorance. There is, he writes

no need of understanding the nature of the soul, or the way in which it acts upon the body, in order to know that the vital motions are owing to it: it is sufficient, if we know from experience, that it feels, is endued with sensation, and has a power of moving the body. ${ }^{14}$

Elsewhere in his Essay on the Vital and Other Involuntary Motions of Animals, Whytt notes that we experience the power of the sentient principle in determining muscular motion both when an external stimulus is present and when we merely have an idea of such an object. He argues that reflection on such phenomena should give us 'less reason to hesitate in admitting' the doctrine of a sentient principle operating unconsciously in the muscles themselves (p. 255).

Whytt's interpretation of the Newtonian 'active power' as a sentient principle makes some sense when seen in the context of his physiological experiments and his experience as a physician with the ever-present phenomena of pain. But perhaps it makes even more sense when it is seen in the context of some of the theories of animal motion put forward by other British authors of his day. 
One of the theories which Whytt is concerned to attack is that which attributes muscular contraction to the peculiar energy of some very subtile ethereal or electrical matter residing in the nerves' (Essay, p. 234). This theory has its roots in Query 24 of the Opticks, where Newton suggested that animal motion might be performed by the vibrations' of an ethereal active medium which are

excited in the Brain by the power of the Will, and propagated from thence through the solid, pellucid and uniform Capillimenta of the Nerves into the Muscles, for contracting and dilating them. ${ }^{15}$

This theory, as developed by Newton, is clearly not materialistic; for the source of the motion is identified as the mind itself. The same is true when the theory is adopted by Henry Pemberton in his Preface to the 1724 edition of William Cowper's Myotomia Reformata ${ }^{16}$ and by George Cheyne in his popular The English Malady of $1733 .{ }^{17}$ However, the aether had clearly been identified as a primary locus of activity in Query 18 of the Opticks. As Bryan Robinson wrote in his Dissertation on the Aether of Sir Isaac Newton (1743):

The aether is the most general of all material causes, from which all particular causes derive their power; and it derives its great power and force immediately from God, who by it governs the material world. ${ }^{18}$

In his earlier Treatise on the Animal Oeconomy Robinson seems to allow for an animal automatism which takes place entirely independently of the mind:

I have shewn that heat, punctures or wounds, and ligatures on the nerves in the instant they are made, have a power of contracting the muscles: and from the effects of vomiting and purging medicines, and some poisons, we learn that the subtile and active particles of some bodies have a like power: but since all these things, however different they are in themselves, do notwithstanding produce the same effect which the will does, they must do it in the same manner, that is, by exciting a vibratory motion in the aether within the nerves and membranes of the muscles. ${ }^{19}$

The aether is a material principle which, while it ultimately derives its activity from the Deity, provides a source of activity within the animal body.

The aether theory in all of its forms involved an attempt to explain nervous and muscular actions by means of the same general physical 
principles which operate in the universe quite apart from animate life. Whytt directed his attacks on the theory to the discussion in the works of Bryan Robinson and Browne Langrish's 'Croonian Lectures on Muscular Motion' (published in the Philosophical Transactions of the Royal Society 1747-48). Whytt argues that such physical theories could only explain how motions can arise from 'a cause particularly adapted to excite' them. The aether theory may explain why heat or electricity applied to the periphery of the body should cause a motion through the nerves, but it is too crude to explain the particular response when 'fibres are pricked, torn, or otherwise separated.' The theory will not account for the specific responses of animal tissue to a wide variety of different stimuli (Essay, pp. 234 et seq.).

While Whytt was concerned to distinguish his own interpretation of 'active power' from that of a physicalist such as Bryan Robinson, he was no less concerned to distinguish it from the principle of animal motion espoused by his Edinburgh colleague, William Porterfield. In his 'Essay concerning the motions of our eyes' which was published in successive volumes entitled Medical Essays and Observations in Edinburgh in 1735 and 1736, Porterfield claimed that 'no body now a-days that understands any thing of Nature and philosophy, can so much as imagine than any animal, how abject soever, can be produced by mechanism, without any active immaterial cause.' Porterfield presents an argument for the existence of such an active principle which is already familiar to us. There can be, he writes, 'no perpetual motion in the present state of things. ${ }^{20}$ Porterfield's argument, which is far less specific than that later put forward by Whytt, shows clear signs of having been adopted from George Cheyne's The English Malady. Cheyne had argued that there must be loss of motion due to the Friction of Bodies, the perpetual loss of communicated motion on our Globe, and the Impossibility of any curves being described by one and the same impulse ...' (op.cit., p. 90). Thus, the need for an active immaterial cause is based on the general Newtonian notion that the material world is running down.

However both Cheyne and Porterfield reject the view that the active power which operates in the bodies of animals is merely the general impression of the Deity on all matter. Cheyne claims that every animal is a perpetuum Mobile' which operates from a non-mechanical 'Self-motive principle within.'21 Porterfield writes against the interpretation of active powers espoused by early Newtonians:

If it should be said, that ... (the motions of animals) do not depend on mechanism alone, but on mechanism join'd with certain active powers or forces, imprinted by the author of nature upon all the bodies of this universe, 
such as are the powers of attraction and repulsion, by which indeed the greatest part of the phaenomena of nature are unquestionably produced; it is incumbent on those who entertain this opinion, to explain particularly how these motions are thus continued by these active principles before they can expect we should believe them..$^{22}$

Porterfield believes that such a general interpretation of active powers can give no genuine explanation of the motions of animal bodies. Like Cheyne, he favours the view that those motions have their source in an active principle in the individual organism itself. This active principle is identified by Porterfield as the individual mind of the organism (p. 223).

Thus far, the views of Cheyne and Porterfield are indistinguishable from those of Robert Whytt. However, unlike Whytt, these authors identify the active principle with the rational mind itself. Porterfield writes that

the mind does not only preside over those motions commonly called voluntary, but ... is constantly employed in the government of all the vital and natural motions, which of themselves would soon stop, were it not for the influence and interposition of this active principle. ${ }^{23}$

He closely follows the view of Georg Stahl that the mind constantly organizes and unconsciously directs the vital operations of the body. The active principle as interpreted by Porterfield is an intelligent principle which acts purposefully (though unconsciously) in the human body both in the original formation of the foetus and in defending the integrity of the body afterwards. I cannot elaborate on his remarkable discussion here, but I do want to suggest that even this interpretation of the active principle has solid Newtonian roots. In the Query 31 of the Opticks, Newton stressed that the 'Uniformity in the Bodies of Animals' as well as that 'in the Planetary System' must involve an act of choice of an intelligent being. While this intelligent being appears to be the Deity himself, there is some reason to think He operates through finite creatures. For the passage immediately follows one where Newton suggests that operations in the world are performed by God through immanent active principles.

In his Essay on the Vital and other Involuntary Motions of Animals, Whytt complains about the 'extravagant flights of Stahl' and his followers like Porterfield (pp. 277 et seq.). In arguing against the view that the soul operates purposefully and with foresight in producing vital operations in the body, Whytt insists that when the soul operates rationally it does so consciously. Reason and foresight require the use of 
ideas and (following Locke) he claims that the 'very existence' of ideas 'depends upon our being conscious of them' (p. 287). On the other hand, Whytt believes that when the soul acts as a 'sentient principle', it does so entirely without consciousness. Moreover, it does so involuntarily. Whytt writes that 'in producing the vital and other involuntary motions' the mind

does not act as a rational, but as a sentient principle; which, without reasoning upon the matter, is as necessarily determined by an ungrateful sensation or stimulus affecting the organs, to exert its power, in bringing about these motions, as is a balance, while, from mechanical laws, it preponderates to that side where the greatest weight prevails. (p. 289; italics mine)

Whytt's own sentient principle is therefore far more limited in scope than the rational animating principle of the Stahlians: it is presented to explain the necessary reactions of living tissue to a stimulus which is applied to it. Unlike the immaterial active principle of Porterfield, it is not an ordering principle which accounts for the symmetry, regularity and purposefulness, to be found in the world of living beings. ${ }^{24}$

Thus we can see that behind the generally accepted view that matter is inert and passive lies a range of philosophical views about the nature and causes of various life phenomena. I hope I have shown that these views may be justly represented as elaborations on the rich Newtonian notion of an 'active power'. Writers like Whytt, Robinson, and Porterfield produced very different interpretations of this power and so very different philosophical physiologies. In this paper I have been particularly concerned to stress the biological richness of Robert Whytt's notion of active power as a 'sentient principle'. I have also suggested that such a notion makes good sense in the context of the philosophical and physical theories prevalent in his own day.

JOHN P. WRIGHT

University of Windsor

\section{Notes}

Support for the research used in this paper has been provided by a Research Grant of the Social Sciences and Humanities Research Council of Canada. 
1 Jacques Roger, Les Sciences de la Vie dans la Pensée Française du XVIIIe Siècle (Paris: Armand Colin, 1963), pp. 163-64.

2 George Cheyne, Essay on Regimen, second edition (London, 1740), p. 148.

3 David Hartley, Observations on man, his frame, his duty, and his expectations (London: S. Richardson, 1749), vol. II, Pt. 2, p. 31.

4 The Leibniz-Clarke Correspondence ed. H.G. Alexander (Manchester and New York: Manchester University Press and Barnes and Noble, 1956), p. 112.

5 Sir Isaac Newton, Opticks or a Treatise of the Reflections, Refractions, Inflections and Colours of Light (London: G. Bell, 1931; reprinted New York: Dover, 1952), pp. 398-99.

6 See Franklin Fearing, Reflex Action (Cambridge, Mass. \& London: M.I.T. Press, 1930), pp. 74-83; Georges Canguilhem, La Formation du Concept de Réflexe aux XVIIe et XVIIIe Siècles (Paris: J. Vrin, 1977), pp. 101-07 et passim.

7 Recently discussed in François Duchesneau, La Physiologie des Lumières (The Hague: Nijhoff, 1982), chapter VI, and Shirley A. Roe, 'Anatomia Animata: The Newtonian Physiology of Albrecht von Haller', in Everett Mendlesohn, ed., Transformation and Tradition in the Sciences, (forthcoming). See also R.K. French, Robert Whytt, The Soul, and Medicine (London: The Wellcome Institute of the History of Medicine, 1969), chapter VI.

8 See Roger, p. 636.

9 Robert Whytt, Essay on the Vital and other Involuntary Motions of Animals, (Edinburgh: Hamilton, Balfour and Neil, 1751), pp. 268-71.

10 Jacques Rohault, Rohault's System of Natural Philosophy, Illustrated with Dr. Samuel Clarke's Notes Taken mostly out of Sir Isaac Newton's Philosophy, translation by John Clarke, 2 Vols. (London: James Knapton, 1723), vol. 1, p. 149 , note 2 .

11 Whytt, Essay, p. 391.

12 ibid., p. 324.

13 Robert Whytt, Observations on ... Sensibility and Irritability ..., in The Works of Robert Whytt (Edinburgh, 1768), pp. 260-61.

14 Whytt, Essay, p. 276; cf. Robert Whytt, Observations on the Nature, Causes and Cure of those Disorders which have been commonly called Nervous, Hypochondriac, or Hysteric, Preface, p. v.

15 Newton, Opticks, pp. 353-54. On the history of the ether theory in physiology see also Roger K. French, 'Ether and Physiology', in G.N. Cantor and M.J.S. Hodge, eds., Conceptions of Ether: Studies in the history of ether theories, 1740-1900 (Cambridge: Cambridge University Press, 1981), 111-134, esp. 120-124.

16 William Cowper, Myotomia Reformata: or, an Anatomical Treatise on the Muscles of the Human Body ... to which is prefix'd an introduction concerning muscular motion, edited by Richard Mead, assisted by Joseph Tanner, James Jurin, and Henry Pemberton (London: R. Knaplock et al., 1724).

17 George Cheyne, The English Malady: or, a Treatise of Nervous Diseases of All Kinds (London: G. Strahan and J. Leake, 1733), pp. 74ff. 
18 Bryan Robinson, Dissertation on the Aether of Sir Isaac Newton (Dublin, 1743), Preface.

19 Bryan Robinson, Treatise on the Animal Oeconomy (Dublin, 1732), p. 99.

20 William Porterfield, 'Essay concerning the notions of our eyes', Medical Essays and Observations, Revised and Published by A Society in Edinburgh, The second edition corrected, vol. IV, (Edinburgh, 1737), p. 219.

21 Cheyne, English Malady, p. 90.

22 Porterfield, 'Essay concerning the motions of our eyes', p. 221.

23 ibid., p. 223.

24. On the difference between the physiological theories of the Stahlians and Whytt, see also François Duchesneau, La Physiologie des Lumières, chapters I and VI, esp. p. 176. 